\title{
PERANCANGAN SISTEM INFORMASI MANAJEMEN EKSTRAKURIKULER (SIME) BERBASIS WEB
}

\author{
Gerlan A. Manu ${ }^{\text {a }}$, Helidorus Tugil ${ }^{\text {b }}$ \\ ${ }^{a b}$ Universitas Citra Bangsa, Nusa Tenggara Timur, 85111 \\ agerlan.manu@gmail.com, ${ }^{\text {bhelidorustugil@gmail.com }}$
}

\begin{abstract}
ABSTRAK
Sistem Informasi Manajemen Ekstrakurikuler berbasis Web pada Sekolah Menengah Pertama Swasta Muhammadiyah Kupang belum menggunakan sistem informasi berbasis web. Sistem informasi ini merupakan sistem informasi yang digunakan untuk membantu memanajemen pelaksanaan kegiatan ekstrakurikuler. Sehingga pengelolaan kegiatan dapat terkontrol dan terdata dengan baik. Dalam pengembangan sistem informasi manajemen ekstrakurikuler pada Sekolah Menengah Pertama Swasta Muhammadiyah Kupang menggunakan metode waterfall, metode studi lapangan dan studi pustaka digunakan untuk pengumpulan data. Sistem informasi ini dibuat menggunakan bahasa pemograman PHP dan database server MySQL. Metode pengujian menggunakan pengujian black box dan usability. Hasil penelitian ini adalah sebuah sistem informasi berbasis website yang dapat memudahkan pengajar, anggota dan kepala sekolah dalam melaksanakan pendataan pelaksanaan kegiatan ekstrakurikuler sehingga dapat terkontrol dengan baik. Hasil pengujian perangkat lunak yang dikembangkan memperoleh hasil nilai functionality sebesar 1 (Baik), pengujian aspek usability memperoleh hasi dengan persentase 94,66\% (Sangat Layak).
\end{abstract}

Kata Kunci : sistem informasi, manajemen ekstrakurikuler, waterfall, website

\section{ABSTRACT}

Web-based Extracurricular Management Information System at Kupang Muhammadiyah Private Secondary Schools has not used a web-based information system. This information system is an information system that is used to help manage the implementation of extracurricular activities. So that the management of activities can be controlled and recorded properly. In the development of extracurricular management information systems at the Muhammadiyah Kupang Private Secondary School using the waterfall method, the field study and library study methods are used for data collection. This information system is created using the PHP programming language and MySQL database server. The testing method uses black box testing and usability.The results of this study are a website-based information system that can facilitate teachers, members and school principals in carrying out the data collection of extracurricular activities so that they can be controlled properly. The results of testing the software that was developed obtained a functionality value of 1 (Good), testing the usability aspect obtained results with a percentage of $94.66 \%$ (Very Eligible).

Keywords: information systems, extracurricular management, waterfalls, website 


\section{PENDAHULUAN}

Umumnya sekolah memiliki beberapa sistem informasi untuk mengontrol manajemen kegiatan disekolah namun, tidak semua sekolah memiliki sistem informasi yang mengontrol manajemen kegiatan ekstrakurikuler. Pemanfaatan Teknologi Informasi dan Komunikasi dalam pengelolaan sekolah menurut Ondi Saondi setidaknya memiliki beberapa manfaat yaitu hemat waktu, dan biaya, peningkatan efektifitas, Pemanfaatan teknologi informasi dalam mengelola lembaga pendidikan merupakan tuntutan mendesak karena persaingan atar sekolah tidak hanya bersifat nasional melainkan juga bersifat global [3].

Sekolah menengah swasta muhammadiyah memiliki tiga kegiatan ekstrakurikuler diantaranya ekstrakurikuler pramuka, pencak silat, dan drum band. Hasil wawancara dengan wakasek bidang kesiswaan mengatakan bahwa kegiatan ekstrakurikuler seperti: (1) jadwal kegiatan, pelaksanaan kegiatan, nilai, tenaga pengajar berupa pengumuman dari pihak sekolah maupun oleh pembina masing-masing kegiatan, (2) pengelolaan administrasi ekskul menggunakan Microsoft Word dan Microsoft Excel, (3) terdapat permasalahan dalam pencarian data dan pengubahan data anggota ekskul, (4) informasi jenis kegiatan, jadwal kegiatan, nilai, dan manajemen tenaga pengajar, sehingga informasi yang dihasilkan masih terpisah berdasarkan jenis ekskul, (5) sekolah menegah swasta Muhammadiyah kupang belum mempunyai sistem informasi untuk memanajemen kegiatan ekstrakurikuler sehingga mengurangi batasan penerima informasi.
Untuk mengatasi masalah tersebut, Penulis memberikan solusi dengan membangun suatu sistem informasi manajemen ekstrakurikuler (SIME) berbasis web, yang dapat mengontrol manajemen kegiatan ekstrakurikuler. Sistem ini diharapkan dapat mempermudah proses manajemen ekstrakurikuler dan dapat memberikan informasi secara luas dalam hal ini komponen yang terlibat dalam kegiatan ekstrakurikuler. Untuk menghubungkan setiap form dan menghindari redudansi data digunakan Relasi Flow Diagram (RAT), Database, serta Data Flow Diagram (DFD) untuk melihat alur sistem. Dalam pembuatan sistem ini digunakan alat bantu pengembangan sistem yaitu PHP dan database MySQL.

\section{METODE PENELITIAN}

Metode penelitian yang digunakan adalah penelitian dan pengembangan (Research and Development), adalah Metode penelitian yang digunakan untuk menghasilkan produk tertentu, dan menguji keefekifan produk tersebut. Perancangan Sistem Informasi Manajemen Ekstrakurikuler (SIME) Berbasis Web yaitu Research and Development R\&D, dengan model waterfall. Model air terjun (waterfall) adalah suatu proses pembuatan sistem informasi secara terstruktur dan berurutan dimulai dari studi kelayakan, investigsi, analisis, perancangan, penerapan, perawatan [2].

\section{Studi Kelayakan}

Studi kelayakan dilakukan untuk melihat apakah pengembangan sistem yang lama perlu dilakukan. 


\section{Tahapan Investigasi}

Tahapan ini dilakukan untuk menentukan apakah terjadi suatu masalah atau adakah peluang suatu sistem informasi dikembangkan dan menelusuri sistem seperti apa yang dibutuhkan. Pada tahapan studi kelayakan ini juga perlu dilakukan untuk menentukan apakah sistem informasi yang akan dikembangkan merupakan solusi yang layak.

Pada tahapan ini peneliti melakukan pengumpulan data dengan cara Observasi, Wawancara, dan Dokumentasi. Menurut Sugiyono, teknik pengumpulan data merupakan langkah yang paling strategis dalam penelitian, karena tujuan utama dari penelitian adalah mendapatkan data [4]

\section{Tahapan Analisis}

Tahap analisis bertujuan untuk mencari kebutuhan pengguna dan organisasi serta menganalisis bagaimana sistem akan dibuat.

\section{Desain}

Tahap ini peneliti melakukan menentukan spesifikasi detil dari komponen-komponen sistem informasi dan melibatkan perancangan dari sistem informasi yang akan dibuat.

Menurut Sukamto dan Shalahuddin (2013:70) Data Flow Diagram (DFD) atau dalam bahasa Indonesia menjadi Diagram Alir Data (DAD) adalah representasi grafik yang menggambarkan aliran informasi dan transformasi informasi yang diaplikasikan sebagai data yang mengalir dari masukan (input) dan keluaran (output). DFD dapat digunakan untuk merepresentasikan sebuah sistem atau perangkat lunak pada beberapa level yang lebih detail untuk merepresentasikan aliran informasi atau fungsi yang lebih detail. DFD menyediakan mekanisme untuk pemodelan fungsional ataupun pemodelan aliran informasi [5]. Berikut adalah DFD Sistem Informasi Manajemen Ekstrakurikuler :

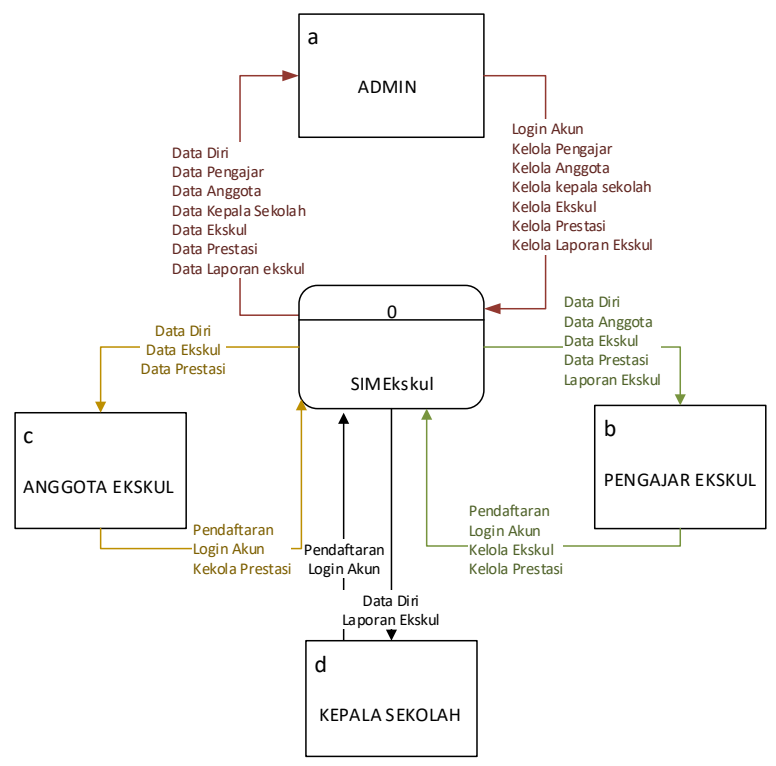

Gambar 1. Diagram Konteks Sistem

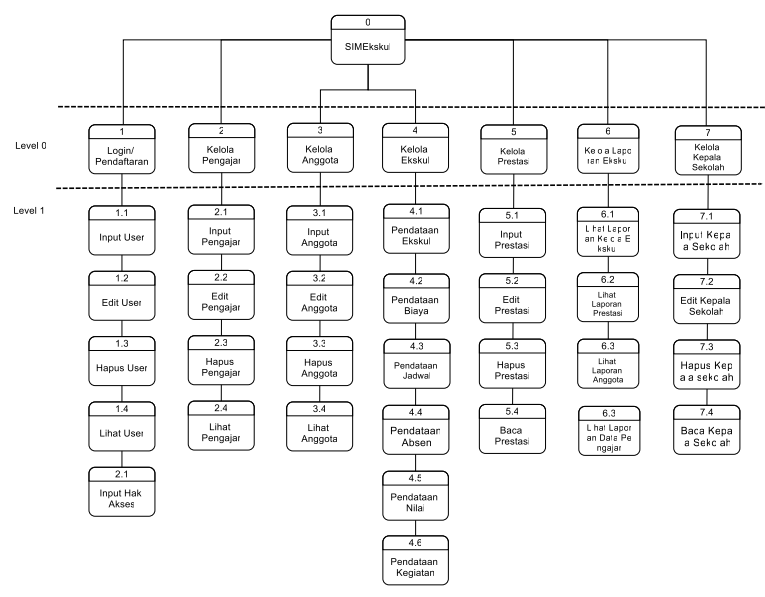

Gambar 2. Diagram Jenjang 


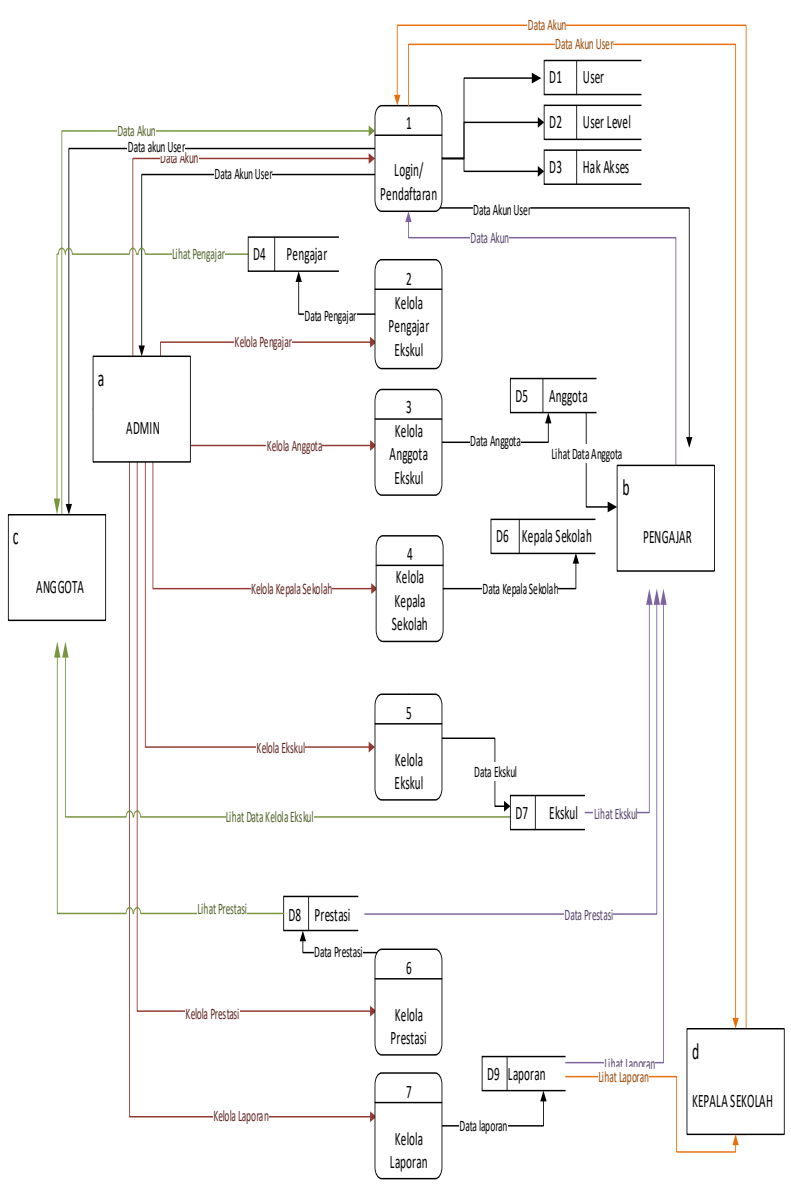

Gambar 3. DFD Level 0

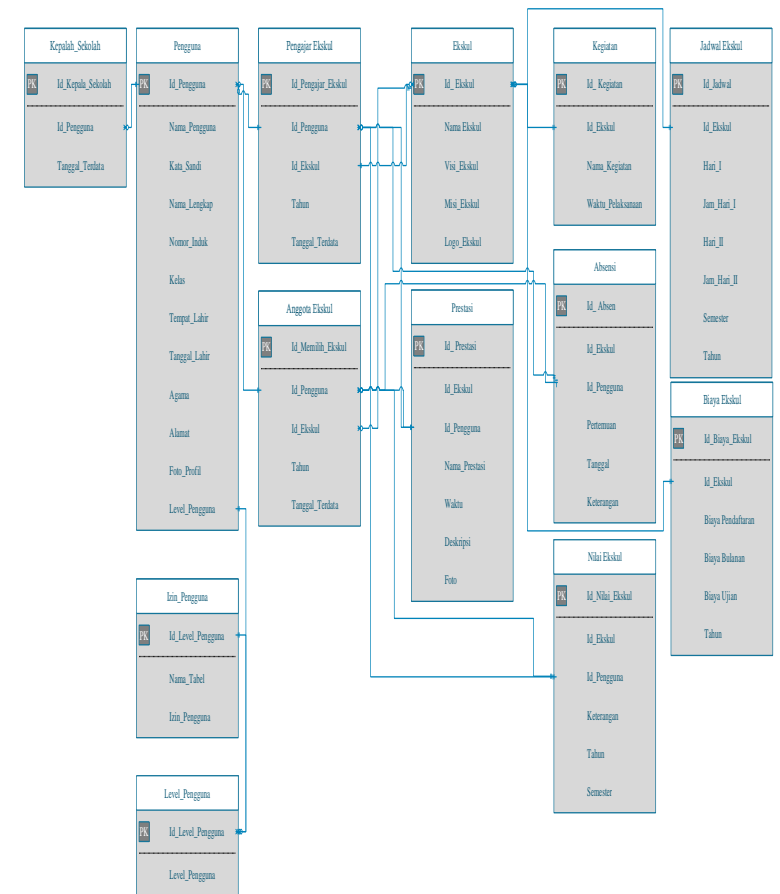

Gambar 4. Normalisasi Tabel

\section{Perancangan User Interface.}

1. Tahapan Penerapan / Coding

Tahapan ini untuk mengimplementasikan tahap desain yang sudah didesain dimana program komputer ditulis atau proses coding, dan testing dan pengjian efektifitas produk. Coding adalah tahap menerjemahkan kebutuhan sistem dari proses desain sistem kedalam program perangkat lunak. Hasil dari tahap ini adalah program komputer sesuai dengan desain yang telah dibuat pada tahap desain.

Tahap testing berfokus pada perangkat lunak dari segi logika dan fungsional untuk memastikan semua bagian sistem telah diuji.

2. Tahapan perawatan

Tahapan perawatan dilakukan ketika sistem informasi sudah dioperasikan. Pada tahapan ini dilakukan monitoring proses, evaluasi dan perubahan (perbaikan) bila diperlukan.

\section{HASIL DAN PEMBAHASAN}

Halaman Login User

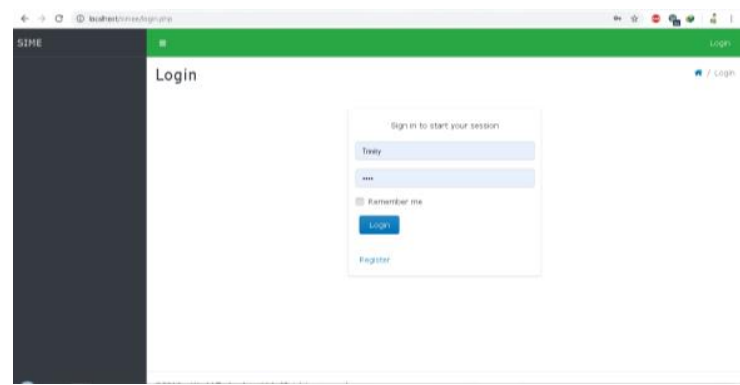

Gambar 5. Gambar 4.1 Login User

Pada tampilan login digunakan untuk menginput nama user dan kata sandi dari pengguna sistem baik itu anggota, pengajar, kepala sekolah dan admin serta registrasi user saat pertama kali mendaftar. 
Halaman Admin

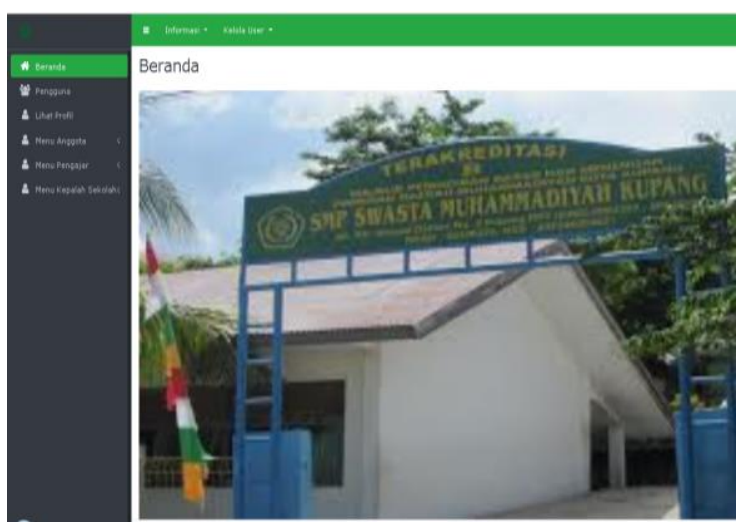

Gambar 6. Halaman admin

Pada tampilan halaman admin terdapat menu informasi yang akan menginformasikan ekstrakurikuler, jadwal ekskul, biaya ekskul, lihat pengajar. Menu kelola user terdapat informasi pengaturan untuk mengelola level pengguna, izin pengguna dan cek user registrasi untuk melihat pengguna yang melakukan registrasi pada sistem. Lihat profil admin, menu pengguna menginformasikan pengguna ekskul yang telah terdaftar, menu anggota, menu pengajar, menu kepala sekolah menginformasikan laporan pelasanaan ekstrakurikuler.

\section{Halaman Pengajar}

Pada tampilan halaman pengajar terdapat menu informasi yang menginformasikan ekstrakurikuler, jadwal ekskul, biaya ekskul, lihat profil pengajar. Menu pengajar dimana pengajar dapat melalukan input data kegiatan, absensi, nilai, prestasi dan melihat anggota ekskul.

\section{Halaman Anggota}

Pada tampilan halaman anggota terdapat menu informasi yang menginformasikan ekstrakurikuler, biaya ekskul, jadwal ekskul, lihat pengajar. Lihat profil pengguna. Menu anggota dimana anggota ekskul memilih ekskul, melihat absen, nilai, prestasi.

\section{Testing}

\section{Validasi Ahli Media}

Pengujian dan Analisis Aspek Functionalty Sebelum produk diuji kelapangan atau lokasi penelitian, terlebih dahulu produk diuji oleh 3 ahli media dengan rumus perhitungan nilai validasi sebagai berikut:

$\mathrm{X}=1-\frac{A}{B}$

Keterangan

$\mathrm{X}=$ Functionalty

$\mathrm{A}=$ Jumlah total fungsi yang tidak valid

$\mathrm{B}=$ Jumlah seluruh fungsi

Presentasi untuk masing-masing penilaian adalah sebagai berikut:

Ya $: 75$

Tidak : 0

Setelah melakukan perhitungan maka didapat hasil sebagai berikut.

$\mathrm{X}=1-\frac{0}{75}$

$\mathrm{X}=1$

Berdasarkan rumus pengukuran implementasi functionalty tersebut, functionalty dikatakan baik jika nilai $\mathrm{X}$ lebih dari 0,5 mendekati 1. Berdasarkan hasil tersebut maka pengujian sistem aspek functionalty dinyatakan layak. 


\section{Pengujian dan Analisis Aspek Usability}

Table 1. Perhitungan Skor Total Pengujian Usability

\begin{tabular}{|c|c|c|c|}
\hline & Jumlah & Skor & Hasil \\
\hline SS & 218 & 5 & 1090 \\
\hline S & 330 & 4 & 1320 \\
\hline RG & 96 & 3 & 288 \\
\hline TS & 0 & 2 & 0 \\
\hline STS & 0 & 1 & 0 \\
\hline \multicolumn{3}{|c|}{ Skor Total } & 2698 \\
\hline
\end{tabular}

Skor total yang telah didapat kemudian dihitung untuk menentukan kualitas. Berikut penyelesaian akhir untuk pengujian usability.

Index $(\%)=\frac{\text { Jumlah Skor Total }}{\text { Nilai Tertingei }} \times 100$

$=\frac{2698}{30 \times 5 \times 19} \times 100$

$=\frac{2698}{2850} \times 100$

$=94,66 \%$

Table 2 Kategori Penilaian Faktor Kualitas Usability

\begin{tabular}{|c|c|}
\hline Interval & Kategori \\
\hline $20 \%-35,99 \%$ & Sangat tidak layak \\
\hline $36 \%-51,99 \%$ & Tidak layak \\
\hline $52 \%-67,99 \%$ & Cukup layak \\
\hline $68 \%-83,99 \%$ & Layak \\
\hline $84 \%-100 \%$ & Sangat layak \\
\hline
\end{tabular}

Berdasarkan table diatas Saragih Ahi (2017), maka hasil presentase pengujian dengan nilai 94,66\% masuk dalam kategori "Sangat Layak" dan memenuhi aspek usability.

\section{KESIMPULAN}

Sistem Informasi Manajemen Ekstrakurikuler (SIME) berbasis web pada Sekolah Menengah Pertama Swasta Muhammadiyah Kupang dikembangkan menggunakan PHP MySQL dan berdasarkan model pengembangan Waterfall yaitu, (1) studi kelayakan (2) investigasi (3) analisis (4) perancangan (5) penerapan (6) peninjauan dan perawatan. Hasil pengujian kualitas perangkat lunak pada aspek usability menghasilkan skor total nilai 2698 yang dikonversikan kedalam skala index mendapatkan nilai sebesar 94,66\%. Kemudian presentase sebesar 94,66\% dikonversikan kedalam skala kualitatif menghasilkan skala penilaian "Sangat Layak". Sehingga dapat disimpulkan sistem informasi manajemen ekstrakurikuler sudah memenuhi aspek usability dinyatakan layak untuk digunakan.

\section{DAFTAR PUSTAKA}

[1]. Olsina, L., Godoy, D., \& Lafuente, G. J., Specifying quality characteristics and attributes for websites", 2003.

[2] Samiaji, Sarosa. Metodologi Pengembangan Sistem Informasi. Jakarta barat: Indeks Jakarta. 2017.

[3] Soandi, Ondi.. Membangun Manajemen Pendidikan Berbasis Sistem Informasi. Bandung: Rofika Aditama. 2014. 
Jurnal Pendidikan Teknologi Informasi (JUKANTI) Volume (3) No (1) April 2020 e-ISSN : 2621-1467

[4]. Sugiyono. Metode Penelitian Pendidikan (Pendekatan Kuantitatif, Kualitatif, dan R\&D). Bandung: Alfabeta. 2016.

[5] Sukamto, Rosa Aryani, dan M.Salahuddin. Rekayasa Perangkat Lunak Terstruktur dan Berorientasi Objek. Bandung : Informatika. 2013. 